\title{
The Impact of Outward FDI on the Upgrading of China's Manufacturing Industry Structure: A Literature Review
}

\author{
Shuyuan Jiang ${ }^{1} \&$ Dan Cheng ${ }^{1}$ \\ ${ }^{1}$ School of Economics and Management, Nanjing University of Aeronautics \& Astronautics, Nanjing, China \\ Correspondence: Dan Cheng, School of Economics and Management, Nanjing University of Aeronautics \& \\ Astronautics, Nanjing, China. Tel: 86-158-5292-8665. E-mail: daisychengdan@163.com
}

Received: April 4, 2017

Accepted: April 19, 2017

Online Published: May 15, 2017

doi:10.5539/ijef.v9n6p154

URL: https://doi.org/10.5539/ijef.v9n6p154

\begin{abstract}
Since China put forward the strategy of "going out", outward foreign direct investment (FDI) began to grow rapidly, and the manufacturing industry, as the pillar industry of our country, is facing the dilemma of transformation. This paper will focus on this topic of the relationship between the outward FDI and upgrading of China's manufacturing industry structure, and sort out and summarize the domestic and foreign literature. It is concluded that the existing literatures are consistent: the outward FDI can promote the upgrading of industrial structure of home country. In terms of China's manufacturing industry, the outward FDI can promote the upgrading of China's manufacturing industry, however, the impact have a kind of hysteresis quality, and may produce the phenomenon of "industry hollowing out".
\end{abstract}

Keywords: outward FDI, upgrading of industrial structure, manufacturing industry, literature review

\section{Introduction}

In the trend of economic globalization drive, in recent years, China's outward foreign direct investment (hereinafter referred to as outward FDI) is booming, the academic circles also focus on attracting foreign investment into the field of outward FDI and focus on the impact of outward FDI on the industrial structure of the home country. This paper focus on this topic of the relationship between outward FDI and upgrading of China's manufacturing industry structure,and then sort out and summarize the domestic and foreign academic achievements in order to provide some clues for the further study of the subject.

\section{Research on Outward FDI}

The research on outward FDI has a long history, and there are a lot of researches on outward FDI from various aspects made by domestic and foreign scholars. The impact of outward FDI on the adjustment of industrial structure is mainly through the industrial transfer effect, industry linkage effect and industrial competition effect. The size of these effects is affected by many factors. This paper focuses on the literature review of the two important factors of the host country's location and motivation.

\subsection{Location Choice}

For enterprises, location choice is an important factor to be considered in outward FDI, which is very important to the investment risk and success or failure (Dunning, 1985).

\subsubsection{Theoretical Research}

Many domestic and foreign scholars have put forward many factors that influence the location choice. Market size and geographical distance have a significant impact on China's outward FDI (Cheng \& Ma, 2007). The location choice of developed and developing countries is different. The outward FDI in developed countries is mainly affected by the size of the market, cost and resources, and the outward FDI in developing countries is mainly affected by the local wages and raw material exports ratio (Cheung \& Qian, 2009). The location choice of the state-owned enterprises and private enterprises is different. The state-owned enterprises are less affected by the political risk factors, mainly invest in the countries with rich natural resources, while private enterprises are more inclined to the countries with large market (Ramasamy, 2010). The location choice of China is affected by the size of the host country, the gross domestic product, the degree of openness and resource endowment (Xiaoxi $\&$ Kevin, 2011). The poor institutional environment and rich natural resources of the host countries can attract 
Chinese outward FDI (Kolstad \& Wiig, 2012).

Host system quality, religious diversity, resources endowment, as well as the host country bilateral cultural and trade links with China on China's outward FDI location choice has significant effect (Zhang \& Wang, 2009). In the process of foreign direct investment, industrial selection and location choice plays an important role, and the location choice also has the difference between different industries (Liu \& Yao, 2012). China's outward foreign direct investment is not too concerned about the host country's political system, namely, voice and accountability, but about the host country government effectiveness, regulatory quality and control of corruption (Wang, 2014). State-owned enterprises and private enterprises also have differences on the location choice of host country, research shows that state-owned enterprises are more inclined to rich resources of foreign markets, and is not sensitive to political factors, however, private enterprises tend to be more stable political environment (Qiu \& Yang, 2015).

\subsubsection{Empirical Research}

Burkey adopt China's outward FDI flow data in 1984-2001 as sample, found that the size of the market, geographic location, inflation and market openness are important locational determinants (Burkey, 2007). Cheung and Qian adopt related data from 31 countries and regions in 1991-2005 as research samples, empirical studies have shown that there is a positive correlation relationship between the host country institutional quality and outward FDI (Cheung \& Qian, 2009). Ramasamy established Poisson regression model and studies have shown that the location choice of state-owned enterprises is mainly in order to access to resources, and location choice of private enterprise is to get the market (Ramasamy, 2012). Through the empirical test, the size of the market, resource endowment and the degree of opening to the outside world have significant positive influence on outward FDI flow, while the technology level of the host country and outward FDI flow exists negative influence (Wang \& Fang, 2011). through data from 2003-2011, using gravity model, analyzed China's outward FDI national differences in location choice(Wang \& Tian, 2013). Liu adopt China's outward FDI flow data to 119 countries and regions in 2003-2014 as sample, and establish Heckman two-phase model and investment gravity model to study the effect of host system for location selection. Studies have shown that the host country's economic system and cultural system has obvious effects on the scale of investment in China's outward FDI, political system was not significant effect on the scale of investment in China's outward FDI.

\subsection{Outward FDI Motivation}

Different motivations of outward FDI affects host location choice, indirectly influenced the country industrial structure changes.

\subsubsection{Theoretical Research}

The outward FDI of multinational company is the motivation in order to avoid shipping costs, access to lower cost of production and natural resources (Markusen \& Maskus, 2002). China's outward FDI motivation can be divided into: resource seeking outward FDI, market seeking outward FDI and technology seeking outward FDI (Buckley, 2007). Resource seeking outward FDI is to get more foreign production resources, such as raw materials and low cost of labor (Amighini et al., 2013). Market seeking outward FDI is to get more market share abroad (Chawla \& Rohra, 2015). Technology seeking outward FDI can direct access to the advanced technology from developed countries, and the parent company can build their own research and development center in the host country with advanced technology and abundant human capital, then they can obtain international market demand information more accurately and develop more new products with the international competitiveness (Wang et al., 2012). The three motivations of outward FDI effect on industrial upgrading is different, and the motivations in descending order affecting industrial upgrading are technology seeking outward FDI, market seeking outward FDI and resource seeking outward FDI (Pan \& Yuan, 2014). Regardless of forward investment or reverse investment, market seeking outward FDI and resource seeking outward FDI are main motivations of China's outward FDI (Wu \& Huang, 2016). China's technology seeking outward FDI affect the result of China's industry upgrade through the technology spillover effect (Guo, 2016).

\subsubsection{Empirical Research}

Neven and Siotis selected four powers in the EC as the host country, and study the main motivation of investment the United States and Japan in the four countries (Neven \& Siotis, 1996). Akbar and Bride used the time series data of Hungary from 1989 to 2001, and the study found that market seeking outward FDI is more conducive to economic development, while resource seeking outward FDI is not conducive to long-term progress and economic development (Akbar \& Bride, 2004). Zhang used the outward FDI data of Chinese enterprises to establish a negative two regression model for empirical research. The results show that China has 
more investment in the host country with resource endowments, such as the number of technical preparation, innovation ability and patent, and China's technology seeking outward FDI is increasing (Zhang et al., 2014).

Qi established a unilateral investment gravity model to empirically study China's technology seeking outward FDI by using the panel data of China's outward FDI in 16 developed countries over the period of 2003 to 2009. The results show that the greater the developed countries' restrictions on China's technology transfer and the export of advanced technology products, the more the technology seeking outward FDI (Qi et al., 2013). Liu and Nei took China's outward FDI in 113 countries from 2003 to 2012 as the sample, and divided the 113 countries into developed and developing countries in these two categories. The empirical results show that China's outward FDI for developed countries is mainly motivated by technology seeking, while outward FDI for developing countries is motivated by resource seeking (Liu \& Nei, 2015). China's outward FDI is also motivated by three types of motivation, namely, tax avoidance, market access and access to resources (Yan \& $\mathrm{Hu}, 2016$ ). By extending the traditional gravity model for empirical analysis, the results show that, in recent years, China's outward FDI of tax avoidance motivation is gradually reduced, and the investment to seize the market and obtain the resources is increasing.

\section{Research on the Influence of Outward FDI on Industrial Structure Adjustment}

As early as 1960, after Hymer put forward the theory of monopoly advantage, scholars at home and abroad began to study the relationship between outward FDI and industrial structure.

\subsection{Theoretical Research}

\subsubsection{Theoretical Research Abroad}

Hymer believes that multinational corporations have the advantage that they can overcome the obstacles in the political, economic and cultural aspects of the host country in the process of foreign direct investment. Vernon divided the product life cycle into three stages, and studied the situation of outward FDI and the international transfer of the products in different stages (Vernon, 1966). Kojima put forward "theory of marginal industry transfer", he take Japan as an investment country as an example, he believes that investment in the country should be their comparative disadvantage of industrial transfer to countries that have a comparative advantage, thus promoting the adjustment of industrial structure of both sides (Kojima, 1987). Louis selected developing countries as the main focus, and put forward "The Theory of Small Scale Technology". He thinks that if the developing countries have the small-scale production technology of labor-intensive industries, and be able to market their own national industry in foreign countries, then their multinational companies also have a certain competitive advantage. Lall put forward "State on Localized Technological Capacities" based on the research of the competitive advantage and investment motivation of India's multinational corporations. After the introduction of the advanced technology from developed countries, developing countries should actively accumulate experience and innovate to make their own competitive advantage in the host country market (Lall, 1983). Ricardo proposed "Theory of Comparative Advantage" (Ricardo, 2005), and he believes that every country should according to the principle of "both of the heavy, two disadvantages of the lesser", meaning that focus on producing and exporting the products with comparative advantage and import with comparative disadvantage. So as to achieve the optimal allocation of resources, and optimize the industrial structure of both sides.

\subsubsection{Domestic Theoretical Research}

The influence of outward FDI on the industrial structure adjustment of home country can be divided into three levels (Wang \& Du, 2002). The first level is the adjustment of the internal structure of the enterprise, that is, using the new mode of production to transform the original enterprise. The second level is the adjustment of the internal structure of the industry, that is, the transfer of the upstream and downstream sectors of the value chain. The third level is the transfer of the structure between different industries, that is, the transfer of enterprises to the new industry. Yuan studied the impact of foreign direct investment on China's industrial structure adjustment, and further compared the differences between the influence of China's outward FDI and the introduction of foreign investment on the adjustment of industrial structure (Yuan, 2008). Huo studied the effect of China's outward FDI on industrial structure adjustment by dividing industry. The results show that the promoting effect of outward FDI of technology intensive industries and labor-intensive industries are particularly obvious (Huo, 2014). Industrial upgrading includes inter industry upgrading and intra industry upgrading (Zhang \& San, 2015). Zhu further studied the regional differences of China's outward FDI based on the impact of China's outward FDI on industrial structure.The results show that the promoting effect of China's outward FDI in the eastern region is more effective (Zhu, 2015). Different types of industries should develop different foreign investment policies.Some industries with excess capacity should take the form of horizontal outward FDI, while higher 
technology content industries should take the form of vertical outward FDI (Liu \& Mao, 2016).

At the same time, some scholars also think that outward FDI will bring some negative effects, of which the most important is "Industrial Hollowing out". Shi studied the relationship between outward FDI and hollowing out in Guangdong province. The results show that the industrial structure is developing towards the direction of "hollowing out" with the expansion of the scale of foreign direct investment in Guangdong Province (Shi \& Zhang, 2013). Liu and Nei took the manufacturing industry as an example,and they believe that the rapid expansion of the size of the outward FDI will make the manufacturing capital flows to the virtual economy, and then there will be the phenomenon of "off the shelf" (Liu \& Nei, 2015). According to the study of the effect of outward FDI on industrial hollowing out in Shandong Province, the results show that the outward FDI of Shandong province has a significant negative impact on the hollowing of the scale and efficiency (Wang, 2016).

\subsection{Empirical Research}

Cozza took China's FDI in 27 European countries as an example.The results show that outward FDI can promote the labor productivity of Chinese enterprises, and the multinational enterprises in China can accumulate experience, improve their competitiveness and promote the upgrading of China's industrial structure (Cozza et al., 2015). Feng and Zhang used the method of co integration test and Granger causality test to analyze the impact of outward FDI on the upgrading of China's industrial structure by using the data from 1985 to 2009 as the sample.The results show that the role of outward FDI in promoting the upgrading of China's industrial structure is limited, and there is a certain lag (Feng \& Zhang, 2011). Using the time series data of China from 1982 to 2012, using the cointegration analysis, error correction and impulse response model, Jia studied the influence of FDI and outward FDI on China's industrial upgrading in the long and medium term (Jia et al., 2014). The results show that outward FDI can promote the rationalization of the industrial structure, and outward FDI on the impact of industrial upgrading in the short term is not obvious, while there is a significant role in promoting in the long term. Based on the data of outward FDI and domestic industrial structure in China from 2003 to 2006, Wang and Liu studied the relationship between FDI and industrial structure by calculating the grey relational grade. The results show that outward FDI promotes the optimization and upgrading of China's industrial structure, in which the outward FDI of mining industry and manufacturing industry has a more significant role in promoting the adjustment and upgrading of domestic industrial structure. Wang compared the scale of outward FDI between 2005 and 2009, and selected the top 14 countries in the world as the evaluation object. She established a multi-dimensional evaluation index system by using grey correlation coefficient, and built the entropy weight TOPSIS performance evaluation model to evaluate the macro performance of outward FDI on China's industrial structure optimization (Wang, 2012). Huo studied the effect of industrial structure adjustment of China's outward FDI by using grey relational theory based on the data of various industries between 2008 and 2012 years in China. The results show that the promoting effect of outward FDI of technology intensive industries and labor-intensive industries are particularly obvious (Huo, 2014). Guo studied the influence of China's technology seeking outward FDI on the upgrading of industrial structure by selecting the industrial structure coefficient and Hoffman coefficient based on the revised Chenery standard model (Guo, 2016).

\section{Research on the Influence of Outward FDI on Manufacturing Industry Structure Adjustment}

\subsection{Theoretical Research}

Bitzer and Kerekes established $\mathrm{C}-\mathrm{D}$ production function model according to the data of 17 OECD countries manufacturing industry, and the results show that outward FDI has a great impact on Knowledge Spillovers (Bitzer \& Kerekes, 2008). Outward FDI will promote the development of the economy, and can optimize the structure of the industry, including manufacturing (Kim \& Lin, 2001). Outward FDI will bring more international capital transfer, and China's outward FDI can promote the manufacturing industry and other related industry structure optimization (Wong \& Chan, 2003). After China's accession to the WTO, outward FDI changed the manufacturing industry agglomeration, optimized the structure of the manufacturing industry (Tuan $\& \mathrm{Ng}$, 2004). China's manufacturing outward FDI is mainly to get their advanced technology in the host country. Due to the continuous expansion of China's oil and iron ore scale, so the manufacturing industry accounted for the overall outward FDI Chinese low and declining (Wang, B. \& Wang, H., 2011). By measuring the rationalization index of the industrial structure of manufacturing industry, Feng analyzed the impact of foreign direct investment on the industrial structure, and the results show that the effect is very weak (Feng, 2009). After the integration of the global value chain, the international division of labor in China's manufacturing industry has changed. The high-tech industry in China is still in the downstream stage of processing equipment, which is not conducive to the optimization and upgrading of the industrial structure of the manufacturing industry (Wang, 
2014). According to the host country's attraction, the internal promotion of the home country, the enterprise's own factors and other factors, Hu analyzed the factors that influence the outward FDI location choice of Chinese manufacturing enterprises ( $\mathrm{Hu}, 2015)$. Liu and Mao studied the adjustment of industrial structure of manufacturing industry by calculating the proportion of the added value of the export of the resource industry and producer services in the value added of manufacturing exports. The results show that if the proportion of the export of producer services increases, it shows that China's manufacturing industry is experiencing the "service", and the industrial structure has been optimized. And from the two dimensions of scale effect and structural effect, they think that different foreign investment strategies should be formulated according to different industries and different types of outward FDI in order to adjust the industrial structure (Liu \& Mao). According to the different motivations of outward FDI, different industries and different regions of China, Liu and Nie analyzed the different scale of China's undertaking international manufacturing transfer (Nei \& Liu, 2016).

\subsection{Empirical Research}

Yang took the panel data of Taiwan manufacturing companies from 1987 to 2000 as the sample, and empirically analyzed the influence of outward FDI on their technological progress. The results show that the technical progress and technical efficiency of Taiwan manufacturing enterprises are directly proportional to the outward FDI activity, and outward FDI promotes the optimization of Taiwan's manufacturing structure (Yang et al., 2013). Based on panel data of Chinese manufacturing enterprises from 2002 to 2007, Huang established a double split model. It is found that outward FDI can promote the productivity of the parent company and optimize the industrial structure, but it is related to the absorptive capacity of the enterprise (Huang \& Zhang, 2017).

Based on the data from 2005 to 2009, Zheng studied the impact of China's investment in ASEAN on China's industrial structure. The results show that China's investment in ASEAN transportation and postal services, finance and manufacturing industries have a significant role in promoting the upgrading of the domestic industrial structure. Finally, the grey correlation degree prediction model is established to predict the investment of China's financial industry and manufacturing industry in the period of 2010-2014 (Zheng, 2012). The manufacturing outward FDI is divided into learning outward FDI and competition outward FDI. Based on the data from 2003 to 2010, Zhang and Wang established the distributed lag model, and used the Almon method to estimate the model, and empirically studied the impact of these two types of outward FDI on the industrial structure of the manufacturing industry. The results show that the learning outward FDI is more conducive to promoting the upgrading of China's manufacturing industry structure than competitive outward FDI (Zhang \& Wang, 2013). Wang and Li constructed the theoretical model of GVC layout, calculated the value chain status index, the value added ability index and the value chain profitability index, and studied the position and value added value of the 13 sub sectors of the manufacturing industry in China (Wang \& $\mathrm{Li}, 2015$ ). Through the construction of the revised Chenery standard model, Zhang calculate the rationalization index and height index of China's manufacturing industry structure (Zhang, 2015).

\section{Conclusion and Prospect}

\subsection{Conclusion}

Through the review of the relevant literature, we can conclude the following conclusions:

1) In theoretical research, on the effects of outward FDI on upgrading the industrial structure of the home country, the study of foreign scholars started earlier, and the domestic research started late, which is related to the implementation of China's opening policy and the economic environment of WTO. Most foreign scholars take the developed countries as the home country, the developing countries as the host country to study, and domestic research focused on China's outward FDI for developed countries and developing countries simultaneously. The home country will consider the choice of location in outward FDI, and there are many factors that influence the location, such as the size of the host country's market, the political system, the distance between the host country and the home country, cultural gap and resource endowment. Many scholars believe that outward FDI can promote the upgrading of the industrial structure of the home country, but some scholars believe that the impact of outward FDI is divided into long-term and short-term, long-term effect is more significant.

2) In empirical research, Foreign scholars have studied the economic effects of foreign trade, employment rate, technological progress, industrial structure adjustment, domestic investment and national income from outward FDI of developed countries. Most of the scholars studied upgrading of industrial structure in China by using time series and panel data, calculating the rationalization index and height index and establishing Chenery standard model and $\mathrm{C}-\mathrm{D}$ model. 


\subsection{Prospect}

Scholars at home and abroad have done a lot of research on the upgrading of manufacturing industry structure and outward FDI, which laid the foundation for the development of this paper. However, in the present stage, the following two points can be improved:

1) At present, the research on outward FDI is mostly based on the whole level, and the outward FDI of different motives, but there is a lack of discussion on outward FDI in different ways. From the perspective of value chain, the entire value chain of a whole industry can be transferred to foreign countries, and one or more of the value chain can also be transferred to foreign countries. Antrà and Yeaple defines the former as a horizontal outward FDI, which defines the latter as a vertical outward FDI (Antrà \& Yeaple, 2014). Since then, Liu and Mao has also carried out research on the basis of this definition, so the value chain of different sectors of the impact of outward FDI on industrial upgrading needs to be further studied (Liu \& Mao, 2016).

2) According to the definition of inter industry upgrading and intra industry upgrading, in the impact of outward FDI on industrial structure, most of the existing research is to explore inter industry upgrading.It means that China's outward FDI has an impact on the adjustment of the three industry proportion in China, and most of the empirical research is to calculate rationalization index and height index. In the study of the impact of China's outward FDI on upgrading of manufacturing industry structure, we should not only discuss the adjustment of the proportion of various factors intensive industry, but also to explore the the change of technology level, processing degree and added value level in each stage of the industry value chain.

\section{References}

Akbar, Y. H., \& Mcbride, J. B. (2004). Multinational enterprise strategy, foreign direct investment and economic development: The case of the Hungarian banking industry. Journal of World Business, 39(1), 89-105. https://doi.org/10.1016/j.jwb.2003.08.001

Amighini, A. A., Rabellotti, R., \& Sanfilippo, M. (2013). Do Chinese state-Owned and private enterprises differ in their internationalization strategies? China Economic Review, 27(4), 312-325. https://doi.org/10.1016/j.chieco.2013.02.003

Antràs, P., \& Yeaple, S. R. (2014). Chapter 2 - Multinational Firms and the Structure of International Trade. Handbook of International Economics, 55-130. https://doi.org/10.1016/B978-0-444-54314-1.00002-1

Bin, Z., \& Baichuan, S. (2015). The influence of China's manufacturing industry participating in international division of labor on upgrading and Upgrading Path Choice_-Based on the perspective of vertical specialization. Industrial Economic Research, 5, 12-20.

Bitzer, J., \& Kerekes, M. (2008). Does foreign direct investment transfer technology across borders? New evidence. Economics Letters, 100(3), 355-358. https://doi.org/10.1016/j.econlet.2008.02.029

Buckley, P. J., \& Clegg, L. J. (2007). The determinants of Chinese outward foreign direct investment. Journal of International Business Studies, 38(4), 499-518. https://doi.org/10.1057/palgrave.jibs.8400277

Changyi, W. (2016). Study on the Industrial Hollowing effect of outward FDI in Shandong Province. Journal of Shandong University of Finance and Economics, 4, 10-17, 34.

Cheng, G. (2016). Research on the effect of China's technology seeking OFDI industry upgrading. Zhejiang University.

Cheng, L. K., \& Ma, Z. (2007). China's Outward Foreign Direct Investment. China's Outward Foreign Direct Investment, 545-578.

Cheung, Y. W., \& Qian, X. (2009). Empirics of chinas outward direct investment. Pacific Economic Review, 14(3), 312-341. https://doi.org/10.1111/j.1468-0106.2009.00451.x

Chunling, Q., Xiaoling, H., \& Ying, F. (2013). Technology seeking, restrictions on technology export to China and foreign direct investment in China. International Trade Issues, 4, 115-122.

Chunxiao, F. (2009). An empirical study on foreign direct investment and industrial structure optimization in China. International Trade Issues, 8, 97-104.

Chyau, T., \& Linda, F. Y. Ng. (2004). Manufacturing agglomeration as incentives to Asian FDI in China after WTO. Journal of Asian Economics, (4).

Cozza, C., Rabellotti, R., \& Sanfilippo, M. (2015). The impact of outward FDI on the performance of Chinese firms. China Economic Review, 36, 42-57. https://doi.org/10.1016/j.chieco.2015.08.008 
Fang, Z. (2015). Empirical Study on the impact of OFDI on industrial structure adjustment in China. Nanjing Tech University.

Fei, N., \& Haiyun, L. (2016). Whether OFDI promotes the transfer of international manufacturing industry: An Empirical Study Based on the perspective of structural transmission mechanism. Economic Review, 4, 3-15.

Haiyun, L., \& Fei, N. (2015). A study on the hollowing effect of outward FDI in Chinese manufacturing industry. Chinese Industrial Economy, 4, 83-96.

Haiyun, L., \& Haiou, M. (2016). The impact of OFDI on export value added. Chinese Industrial Economy, 7, 91-108.

Hong, Z., \& Jian, W. (2009). A study on the relationship between host country location and OFDI in China: Empirical evidence based on Quantile Regression. Chinese Industrial Economy, 6, 151-160.

Jianzhao, L., \& Chengfei, Y. (2012). Analysis on the choice of industry and location choice of foreign direct investment in China. Journal of Liaoning Normal University (Social Science Edition), 5, 614-618.

John, H., Dunning, Chang-Su, K., \& Jyh-Der, L. (2001). Incorporating Trade into the Investment Development Path: A Case Study of Korea and Taiwan. Oxford Development Studies, 29(2), 145-154. https://doi.org/10.1080/13600810123926

Juan, W., \& Liangjing, F. (2011). A study on the influence factors of location choice of China's outward FDI-Based on the perspective of national differences. Social Scientists, 9, 79-82, 87.

Kojima, K. (1987). Foreign Trade Theory (Zhou Baolian translation, pp. 10-120). Nankai University Press.

Kolstad, I., \& Wiig, A. (2012). What determines Chinese outward FDI? Journal of World Business, 47(1), 26-34. https://doi.org/10.1016/j.jwb.2010.10.017

Lan, W. (2014). The influence of global value chain on the international division of labor in Chinese manufacturing industry. Statistical Research, 5, 17-23.

Lan, W., \& Hongyan, L. (2015). A study on the integration of China's manufacturing industry into the global value chain-From the perspective of embedded position and value added capability. Chinese Industrial Economy, 2, 76-88.

Lei, Z. (2012). Outward FDI and the upgrading of industrial structure: An analysis based on China's direct investment in ASEAN. Economic Problem, 2, 47-50.

Liu, S., \& Jie, Z. (2013). Study on the correlation between foreign direct investment and industrial hollowing out in Guangdong Province-Based on Grey Relational Analysis. International Business (Journal of University of International Business and Economics), 2, 52-64.

Markusen, J. R., \& Keith, E. M. (2002). Discriminating Among Alternative Theories of the Multinational Enterprise. Review of International Economics, 10(4), 694-707. https://doi.org/10.1111/1467-9396.00359

Min, L., Jinshan, L., \& Yupei, L. (2016). Home country investment motivation, host country system and location choice of foreign direct investment. Explore the Economic Problems, 8, 100-112.

Minglan, Y. (2008). Research on the influence of foreign direct investment on industrial structure adjustment in China. Nanjing University of Aeronautics \& Astronautics.

Neven, D., \& Siotis, G. (1996). Technology Sourcing and FDI in the EC: An Empirical Evaluation. International Journal of Industrial Organization. https://doi.org/10.1016/0167-7187(95)00510-2

Nisha, J.,Yonghui, H., \& Jianhua, Z. (2014). The effect of upgrading the industrial structure of bidirectional FDI in China: Theoretical mechanism and empirical test. International Trade Issues, 11, 109-120.

Ramasamy, B., Yeung, M., \& Laforet, S. (2012). China's outward foreign direct investment: Location choice and firm ownership. Journal of World Business, 47(1), 17-25. https://doi.org/10.1016/j.jwb.2010.10.016

Sheng, W., \& Tao, T. (2013). Study on the factors influencing the location choice of China's outward FDI-Based on the perspective of national differences. World Economic Research, 12, 60-66, 86.

Sukun, P., \& Ran, Y. (2014). Theoretical and Empirical Study on the promotion of industrial upgrading by different investment motives OFDI. Economist, 9, 69-76.

Vernon, R. (1966). International Investment and International trade in the product cycle. Quarterly Journal of Economics, (3), 80. https://doi.org/10.2307/1880689

Wang, B., \& Wang, H. (2011). Chinese Manufacturing Firms' Overseas Direct Investment (ODI): Patterns, 
Motivations and Challenges. Social Science Electronic Publishing.

Wang, C., Hong, J., Kafouros, M. et al. (2012). What drives outward FDI of Chinese firms? Testing the explanatory power of three theoretical frameworks. International Business Review, 21(3), 425-438. https://doi.org/10.1016/j.ibusrev.2011.05.004

Wong, J., \& Chan, S. (2003). China's Outward direct investment: Expanding Worldwide.

Xianming, W., \& Chuntao, H. (2016). The motivation of Chinese enterprises' outward FDI: A comparative study of reverse investment and forward investment. Chinese Industrial Economy, (1), 99-113.

Xiaojun, J., \& Ling, D. (2002). Foreign investment theory and its reference to China. Economic Research Reference, 73, 32-44.

Xiaoxi, Z., \& Kevin, D. (2011). The determinants of China's outward foreign direct investment. Emerging Markets Review, (4).

Xin, H. (2014). A study on the effect of OFDI industrial structure adjustment in China: An Empirical Analysis Based on Grey Relational Theory. International Trade Exploration, 9, 24-32.

Xueling, Y., \& Yang, H. (2016). Institution, culture and interest motivation of Chinese OFDI. Southern Economy, (6), 1-17.

Yang, S. F., Chen, K. M., \& Huang, T. H. (2013). Outward foreign direct investment and technical efficiency: Evidence from Taiwan's manufacturing firms. Journal of Asian Economics, 27(27), 7-17. https://doi.org/10.1016/j.asieco.2013.04.007

Ying, W. (2012). OFDI macro performance evaluation based on industrial structure optimization in China. World Economic Research, 4, 71-89.

Ying, W., \& Sifeng, L. (2008). The impact of OFDI on China's industrial structure: An analysis based on Grey Relational Analysis. World Economic Research, 4, 61-65, 89.

Yongqin, W., Julan, D., \& Kai, W. (2014). Determinants of location choice of China's outward FDI: Institution, tax burden and resource endowment. Economic Research, 12, 126-142.

Youxing, H., \& Yan, Z. (2017). How does outward foreign direct investment enhance firm productivity? A heterogeneous empirical analysis from Chinese manufacturing. China Economic Review, 1-15.

Yun, Z., \& Xin, W. (2013). An empirical study on the relationship between ODI and industrial structure upgrading of China's manufacturing industry based on ODI classification. Technical Economy, 1, 44-50.

Yunda, Z. (2015). A study on the impact of OFDI on China's manufacturing industry structure optimization. Zhejiang University.

Zhang, J., \& Yi, C. (2014). University H. Technology Endowment and Location Choice of Chinese OFDI - The Moderating Effect of Cultural Distance. Journal of Industrial Technological Economics, 2014.

Zhengqiang, F., \& Yan, Z. (2011). An empirical study on the relationship between foreign direct investment and industrial structure adjustment in China. Economic Research Guide, 22, 147-148.

Zijiao, H. (2015). An analysis of the factors affecting the location choice of China's manufacturing industry foreign direct investment. Jiangxi University of Finance and Economics, 2015.

\section{Copyrights}

Copyright for this article is retained by the author(s), with first publication rights granted to the journal.

This is an open-access article distributed under the terms and conditions of the Creative Commons Attribution license (http://creativecommons.org/licenses/by/4.0/). 